\title{
沖合津波観測データ同化システムの開発
}

\section{Development of Tsunami Forecasting System Based on Offshore Tsunami Data Assimilation}

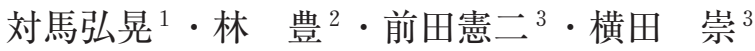 \\ 川上博隆 ${ }^{4}$. 平田 怜 ${ }^{4}$. 吉村健二 ${ }^{4} \cdot$ 遠藤清隆 $^{4} \cdot$ 木田洋祐 ${ }^{4}$ \\ Hiroaki TSUSHIMA, Yutaka HAYASHI, Kenji MAEDA, Takashi YOKOTA \\ Hirotaka KAWAKAMI, Satoshi HIRATA, Kenji YOSHIMURA, Kiyotaka ENDO and Yosuke KIDA
}

\begin{abstract}
We Meteorological Research Institute and NEC Corporation developed a prototype system for real-time prediction of near-field tsunamis using offshore tsunami data. The system is based on tsunami source inversion to forecast coastal tsunami waveforms. Because the system is designed smartly, the single forecasting calculation can be accomplished within a few minutes. Once a trigger in the system is activated, the forecasting calculation starts automatically and is carried out repeatedly at short time intervals by renewing the offshore tsunami data. The figures of the forecasting results are produced automatically and a user can view them with a Web browser. This software is installed on hardware consisting of servers for real-time analyses and large amounts of storage for the database of Green's functions constructed by Kokusai Kogyo Co. Ltd.
\end{abstract}

\section{1. はじめに}

津波の即時予測は，津波被害を軽減する有効な手段の 一つである. 地震発生後に迅速かつ正確に津波を予測し, それに基づく津波注警報を適切に伝達することができれ ば，避難をはじめとする災害対策行動の指標として機能 し，被害の軽減に大きく貢献することが期待される.

沖合津波計は, 津波が沿岸に来るより前に津波を直接 捉えうるため, 津波注警報の発表や更新に有効である. 2011 年東北地方太平洋沖地震 $\left(M_{w} 9.0\right)$ においては, 気 象庁はGPS 波浪計の観測情報を活用して津波注警報第一 報を更新した（気象庁，2011）。また，著者らは，これ までの研究で, GPS 波浪計及びさらに沖合のケーブル式 海底水圧計の観測情報を活用して津波即時予測を行うた めのアルゴリズムを提案し, 東北地方太平洋沖地震等の 過去の実記録への適用により，その性能を示してきた (Tsushima ら，2009, 2011, 2012). 著者らは，同アルゴリ ズムを根幹とする津波即時予測システムの試作版とし て, 平成 23 年度第三次補正予算を活用し, 沖合津波観測 データ同化システムを平成 24 年 7 月までに開発した。本 稿では，開発したシステムについて紹介する。

\section{2. 津波即時予測アルゴリズム}

本研究で開発する沖合津波観測データ同化システム は, 津波波形逆解析による波源推定を活用した津波即時

\begin{tabular}{lllll}
\hline 1 & 正会員 & 博 (理) & 気象研究所 & 地震火山研究部 \\
2 & 正会員 & 博 (工) & 気象研究所 & 地震火山研究部 \\
3 & 非会員 & 博 (理) & 気象研究所 地震火山研究部 \\
4 & 非会員 & & 日本電気株式会社
\end{tabular}

予測アルゴリズムtFISH（tsunami Forecasting based on Inversion for initial sea-Surface Height: Tsushima ら, 2009) 及び沖合と沿岸の津波波高の経験的な増幅率（林，2010） の2つを根幹とする. tFISHは, 津波波源から生じる津波 は，波源を分割した小波源から生じる津波の線形結合で 表現できる，という重ね合わせの原理を利用するもので, 安田ら (2007), 辰巳・富田（2008）をはじめとした研究 で開発・改良されている手法と同様の設計思想に基づく. tFISHでは, 沖合で観測される津波波形デー夕を最も適切 に説明する初期水位分布を逆解析で推定し, 求めた分布 とあらかじめ計算しておいた理論津波波形（グリーン関 数）との線形重ね合わせ計算により予測津波波形を合成 する. 一方, 林 (2010) による波高増幅率は, 過去の津 波記録の分析に基づくもので, 沖合波高から沿岸波高へ の換算を可能にする. 線形近似の妥当性が高い水深まで はtFISHで波形予測を行い, そこよりも浅い水深の場所へ は増幅率を用いて波高を換算して津波予測を行う。

\section{3. 沖合津波観測データ同化システム}

本研究で開発した沖合津波観測データ同化システム は, 次の3つの要素から構成される：

・沖合津波観測データ同化処理装置

・沖合津波観測データ同化ソフトウェア

・沖合津波観測データ同化用理論波形データベース

沖合津波観測データ同化処理装置及びソフトウェアは, 波源推定に基づく津波即時予測を行うためのものであ る. 迅速な津波予測を実現するために, 地震後の解析を 短時間で完了できるように留意しながら開発した。また， 地震後の即時解析のみならず, 事前の準備計算も円滑に 


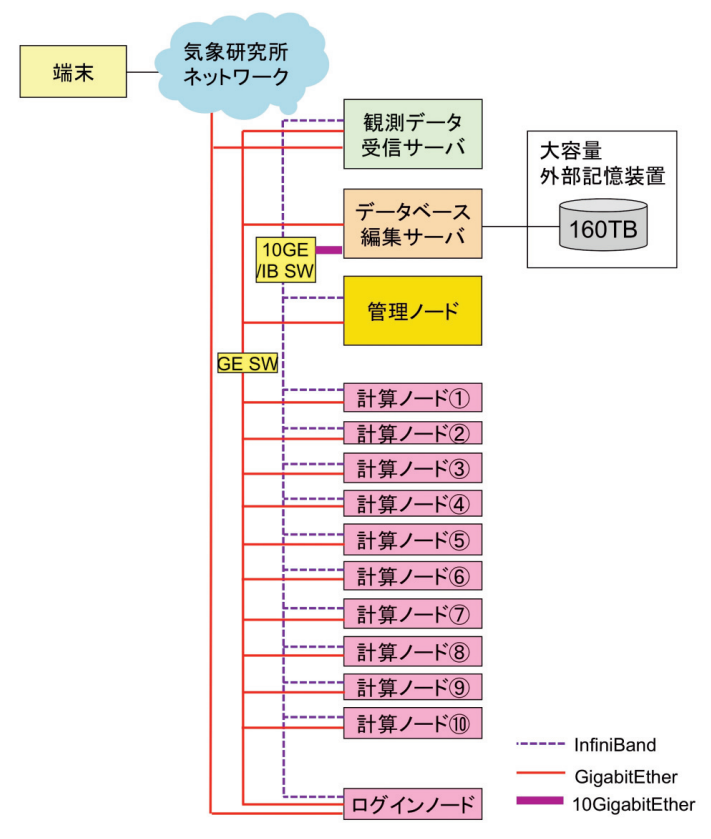

図-1 沖合津波観測データ同化処理装置

進めるための支援システムも含まれる。理論波形デー夕 ベースは，同化ソフトウェアによる津波予測計算で必要 な理論津波波形のグリーン関数群を大量に収録している. 将来の拡張性も考慮した上で設計し複数の品質管理手順 を経ながら，気象研究所と国際航業株式会社が構築した。

（1）沖合津波観測データ同化処理装置とソフトウェア

沖合津波観測デー夕同化処理装置は, 複数のサーバ群 と大容量外部記憶装置で構成される（図-1)。同装置に沖 合津波観測デー夕同化ソフトウェア及び理論津波波形デ ータベースが組み込まれており，このうち，管理ノード が同化ソフトウェアによるリアルタイム津波予測解析の 制御を行う（図-2）。リアルタイム制御を起動させると， 外部から入力される震源情報（震源時, 震源位置, マグ ニチュード）を監視し，マグニチュードが事前設定され た閾值を超えると，自動的に津波予測計算が開始する. 処理装置には 10 台の計算ノードが装備されており（図1)，管理ノードからジョブが投入され予測計算が行われ る。一連の予測計算（図-2の網掛け部分）が終了すると， 予測結果を揭載したウェブページが自動生成される。ま た，こうした一連の予測計算は，一度行ったら終了する のではなく，設定された時間が経過する毎に，その時点 で得られている最新の観測記録を用いて繰り返し自動実 行され，地震発生後一定時間が経過すると停止する。

本システムの予測解析で用いられる観測波形デー夕 は，観測デー夕受信サーバによって受信される，外部か ら WIN（http://eoc.eri.u-tokyo.ac.jp/WIN/）のパケット形式

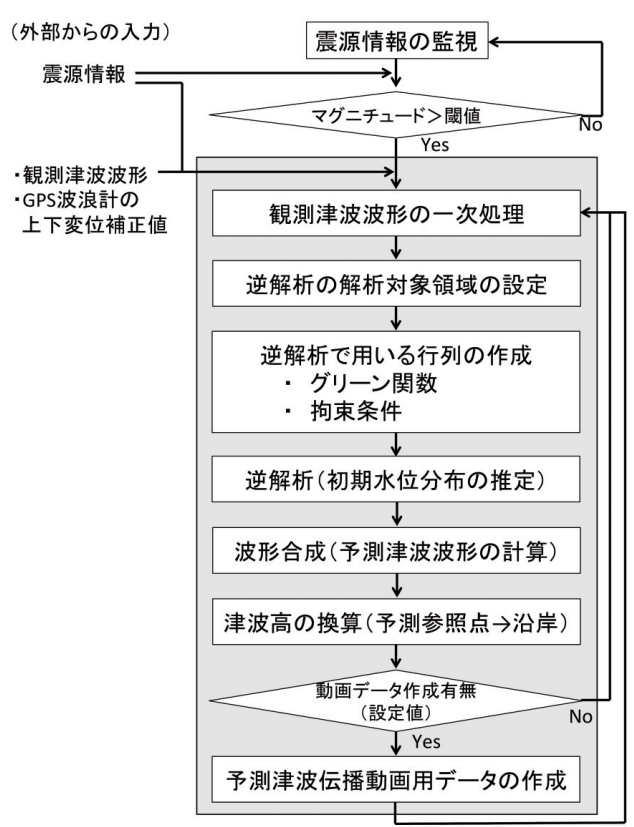

図-2 沖合津波観測デー夕同化ソフトウェアの津波予測解析

で送信されてくる波形デー夕を受信後，予測解析で参照 しやすいように，管理ノードのNFS 領域にテキスト形式 で保存する。また，あらかじめオプション指定しておく と, 理論潮汐モデルNAO.99Jb（Matsumotoら，2000）に よる海洋潮汐成分の除去処理も同時に行われる.こうし た処理は，管理ノードのリアルタイム制御及び地震発生 の有無とは独立に，観測データ受信サーバによって常時 行われる，そのため, 地震発生後に津波予測解析が開始 すると，直ちに観測波形を渡すことが可能である.

リアルタイム津波予測解析（図-2）が震源情報による トリガーで開始すると，沖合観測津波波形を読み込み， ローパスフィルタ（斎藤，1978）による短周期圧力ノイ ズ除去等によって津波成分（及び，海底水圧計の場合は 永年海底変動に伴う水圧変化）が抽出され，逆解析に用 いる波形が切り出される. なお, 陸上基準局の上下変動 に伴う GPS 波浪計記録のみかけのオフセット変化につい ても, 上下変位補正值が外部入力されれば一次処理の中 で補正される. 一次处理後, 逆解析の解析対象領域が設 定される。逆解析では，この領域内に含まれる小波源に ついての初期水位量が推定される。 Tsushimaら（2009） と同様, 逆解析で用いる沖合津波観測点のいずれかの観 測波形に影響を及ぼしうる海域範囲を解析対象領域とす る.この処理は, 同化ソフトウェアが有する支援システ ムを用いて事前準備しておくことで, 短時間で完了する. 領域設定が完了すると, 各小波源での初期水位量が，(1) 式を観測方程式とする逆解析により推定される. 


$$
\left(\begin{array}{c}
\mathbf{f}(t) \\
\mathbf{0} \\
\mathbf{0}
\end{array}\right)=\left(\begin{array}{c}
\mathbf{G}(t) \\
\boldsymbol{\alpha} \mathbf{S} \\
\boldsymbol{\beta D}
\end{array}\right) \mathbf{a} \quad(0 \leq t \leq T) \text { for } t=T \quad \cdots(1)
$$

ここで, $\mathbf{f}(t)$ は沖合津波観測波形を要素とするべクトル, aは各小波源での初期水位量を要素とするべクトル，Tは 予測計算を実施する時刻を示す．S，Dはそれぞれ空間平 滑化拘束条件，震央位置を基準としたダンプ拘束条件の 行列， $\alpha, \beta$ は各拘束強さを示す. $\mathbf{G}(t)$ はグリーン関数 を要素とする行列であり, 各グリーン関数は, 逆解析で 比較対象となる各観測点の観測波形と同じ時間長である 必要がある。しかし, 実際の津波予測の場面では, 予期 せ女理由で観測波形が久測状態に陥ることもあるため, グリーン関数行列の作成は, 地震発生後に欠測状況が判 明してから行う必要がある。ただし，グリーン関数は小 波源と観測点の組合せ分だけ存在するため, 膨大な数の グリーン関数ファイルへのデータ入出力が，リアルタイ ム処理時間のボトルネックになる恐れがある．本システ ムでは，この処理時間の短縮を実現できるように，グリ ーン関数ファイルの保存方法を決定した。なお，ここで 用いるグリーン関数は, 理論波形データベースから抽出, 加工されたものである (次節参照)。ダンプ拘束条件行 列の作成には, 外部入力された震央位置情報を用いる. こうして得られた観測波形と各行列を用いて, 特異值分 解法（Intel MKLのLAPACK95）により初期水位分布を 推定する. 求めた分布を用いた予測津波波形の合成につ いても，短時間処理できるようなファイル保存方式を採 用した。こうして計算される津波予測地点 (FP ; 気象庁 の津波予測で用いられる仮想的な沖合地点）での予測津 波波形に波高増幅率を乗じて, 沿岸における予測津波波 形が得られる.ここまでの処理が完了すると, 初期水位 分布と沖合・沿岸の予測津波波形の図及びそれらを揭載 したウェブページが自動生成される(詳細は4章を参照). また, 事前にオプション指定することで, 逆解析で求め た初期水位分布を波源として津波が周囲に広がっていく 様子を数值化したデー夕も計算できる。ただし，この計 算は少なくとも 5 分程度を要するため, 主たるリアル夕 イム解析の遅延につながらないように, 別ジョブとして 扱われる。

（2）沖合津波観測データ同化用理論波形データベース 沖合津波観測デー夕同化ソフトウェアによる線形解析 では理論津波波形のグリーン関数が必須であるため，東 日本の千島・日本海溝沿い及び西日本の南海卜ラフ沿い の計 2 海域を対象として, グリーン関数群のデータベー スを作成した（図-3). 計算領域内に多数の小波源を配置 し, 各小波源で生じる津波を数值計算して理論津波波形 を求めた，津波の伝播計算には，東北大学から公開され
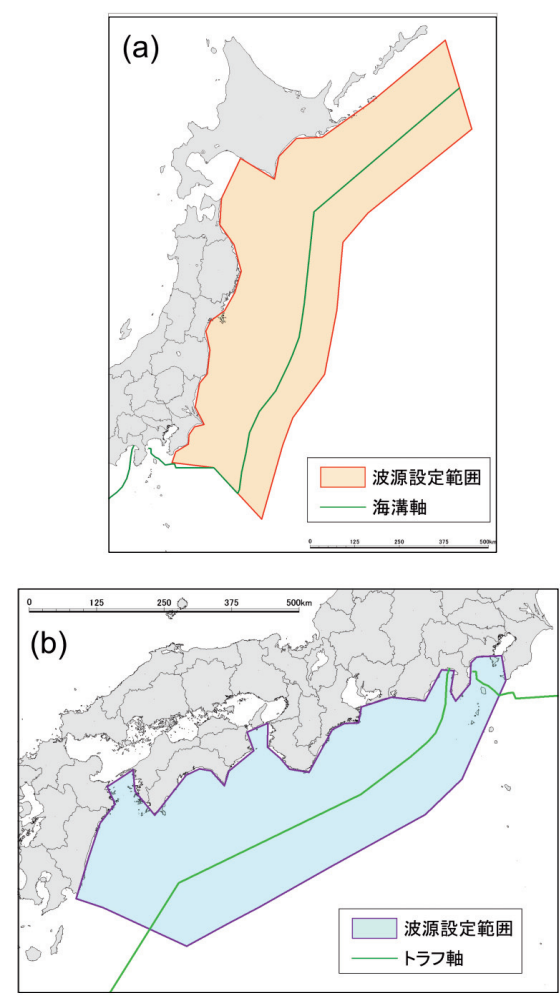

図-3 小波源の設定範囲 (b) 南海トラフ周辺

ている線形長波方程式を差分化した計算コードを用い た。海底地形デー夕は，600, 200, 50 mサイズのメッシュ をネスティングした。 小波源の形状は，(2)式で表され る二次元ガウス関数とした.

$$
h(x, y)=h_{0} \exp \left[-\frac{\left(x-x_{0}\right)^{2}+\left(y-y_{0}\right)^{2}}{(L / 2)^{2}}\right]
$$

ここで, $h(x, y)$ は地点 $(x, y)$ の初期水位量を表す. $\left(x_{0}, y_{0}\right)$ は小波源の中心位置の座標を表し, そこでの初期 水位変位量 $h_{0}$ は $1 \mathrm{~m}$ とした. ライズタイムは 10 秒とした. $L$ は小波源のサイズで, $L=20,40,80 \mathrm{~km}$ の3 種類を用いた. 各サイズの小波源を, 両対象海域における地震発生領域 （図-3）にそれぞれ規則的に配置し，計 3345 個の小波源に ついて津波数值計算を実施した. $L=20,40 \mathrm{~km}$ の小波源に ついては地震発生から 3 時間後, $L=80 \mathrm{~km}$ につてて6時 間後までの津波を計算した。理論津波波形の出力点は, 両対象海域内の沖合・沿岸の津波観測点及びFPから選ん だ計 664 点で, 10 秒毎の計算值を出力した. また, 将来 新たな観測点が追加された際，そこでのグリーン関数も 作成できるように，対象海域内の格子点を一定間隔で間 引いた点での計算值も保存した。こうした大量の計算結 果の品質管理は, 自動点検サブルーチン組达と津波伝播 
(a)

\begin{tabular}{|c|c|c|c|c|}
\hline 受信時刻 & 地震発生時刻 & 震源位置 & 震源深さ $(\mathbf{k m})$ & $\mathrm{M}$ \\
\hline 2013-05-15 15:33:38 & 2011 1-03-11 14:46:18 & 38.0N 142.9E & 24 & 9.0 \\
\hline \hline
\end{tabular}

\begin{tabular}{|c|c|c|c|c|c|c|c|c|}
\hline 計算開始 & 計算終了 & 動画 & i 平滑化拘束 & 隇衰拘束 & (予約) & ) (予約) & ) (予約) & ）経過時間 \\
\hline 2013-05-15 15:33:51 & 2013-05-15 15:36:09 & - & 0.10 & 1.00 & - & - & - & 30 \\
\hline 沖合観測点津波波形 & 予測地点津波波形 & & 源分布 & & & & & \\
\hline
\end{tabular}

(b)

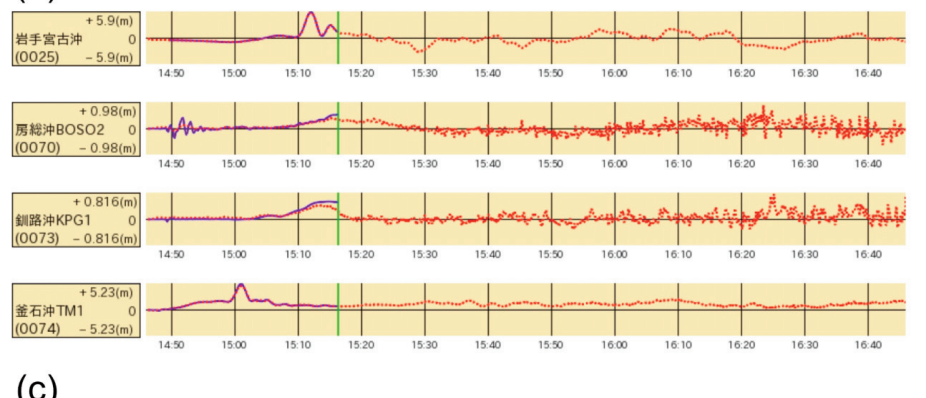

(c)

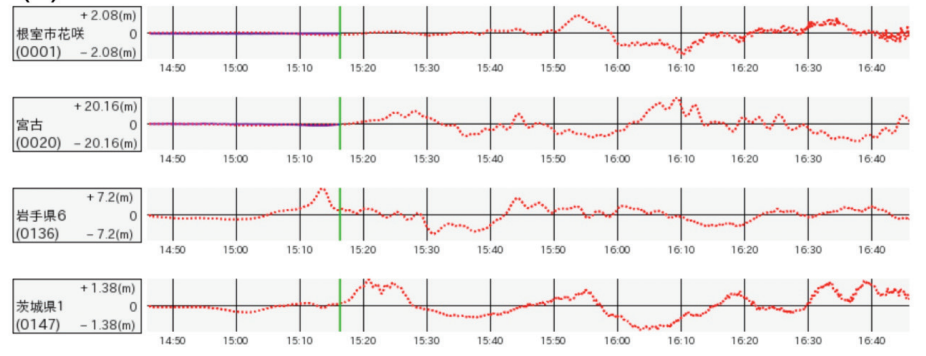

図-4 津波予測結果表示画面の例 （a）解析条件等 (b) 沖合観測点波形の比較 (d)

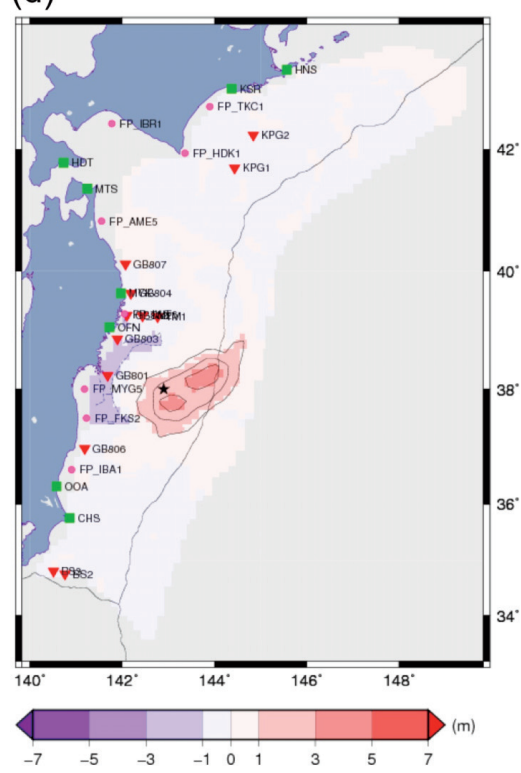

(c) 予測地点波形の比較 (d) 波源分布

動画の目視確認により行った. 得られたグリーン関数は, 処理装置のうち大容量外部記憶装置に収録され，データ ベース編集サーバからデータベース管理システムを用い てデータの抽出・編集が可能である（図-1）。実際の運用 では，上記のデータベースから，同化ソフトウェアで津 波予測対象とする地点のグリーン関数をあらかじめ抽出 してサブデータベースを構築し，管理ノードのNFS 領域 に配置しておく.

\section{4. 動作例}

本研究で開発した沖合津波観測データ同化システムの 動作確認のため, 2011 年東北地方太平洋沖地震の実記録 を用いた試験を実施した。本システムには観測波形デー 夕受信から予測計算までのリアルタイム動作をシステム 内部でシミュレートする機能があり，ここではその一部 を用い，データ受信後の動作をシミュレートした。グリ ーン関数としては, 理論波形データベースのうち, 東日 本用の $L=20 \mathrm{~km}$ の 1740 小波源，沖合・沿岸・FPの計 211 観測点のものを用いた. 気象庁の震源情報を入力情報と して用いた。逆解析に用いた沖合津波波形は，房総沖， 釜石沖, 釧路沖の6点のケーブル式海底水圧計（藤沢ら,
1986; Kanazawa • Hasegawa, 1997; Hirata ら, 2002) と6点 の GPS 波浪計（Katoら，2005）の計12点の実記録である. GPS 波浪計の上下変位補正量としては, Ohta ら（2012） の解析結果のうち, 各波浪計に最も近い, 国土地理院の GEONET 観測点での地震時上下変位量を用いた.

動作試験では, 地震発生後 10 分から50分まで 10 分お きに津波予測解析を実施した。各時刻の計算はいずれも 2 分程度で完了し, 迅速さが重要な即時予測に有効であ ることがわかった. また, 東北地方太平洋沖地震の津波 記録には欠測が含まれるが（例えば，釜石沖ケーブル式 海底水圧計)，そうした欠測状況をシステムが適切に判 断し, 津波予測解析が正常に完了することも確認された. 自動生成された津波予測結果の表示画面の例として, 地 震発生後 30 分の結果を図-4に示す。表示画面では, 震源 情報や解析条件等が基本情報として画面上段に（図-4 (a)), 予測解析結果が下段に表示される. 解析結果とし ては，沖合観測点津波波形（図-4 (b)）と予測地点津波波 形（図-4(c)), 波源分布（図-4(d)）の三項目が表示され, タブ選択により項目が切り替わる。沖合観測点津波波形 の表示画面では, 沖合津波観測点の観測波形と計算波形 が表示され，このうち逆解析に用いた沖合波形の背景に 
は色が付く（図-4 (b) では橙色)。緑色の縦線は計算開始 時刻を示す. 波形表示する時間長や, 波形の線種・色は, ウェブブラウザ上で変更できる. 予測地点津波波形の表 示画面では, 予測地点の観測波形と予測波形が表示され る (図-4 (c)). 波源分布の表示画面では, 逆解析で求め た初期水位分布がカラースケールと等值線で表示される (図-4 (d)).カラースケールの変更や観測点シンボル等の 表示有無は, ウェブブラウザ上で変更できる.

\section{5. おわりに}

本研究では, 沖合津波計の観測記録を活用して津波即 時予測を行う機能を有する沖合津波観測データ同化シス テムを開発した。本システムは，沖合津波観測デー夕同 化処理装置とソフトウェア，理論波形データベースで構 成され, リアルタイム津波予測解析の高速化及び理論津 波波形の品質管理に留意し, 工夫を凝らした上で制作さ れたものである．2011年東北地方太平洋沖地震の観測記 録を用いた動作確認の結果, デー夕久測がある場合でも 正常に処理され, 一回の津波予測解析が 2 分程度で計算 が完了した。このことは, 本システムが, 津波即時予測 にとって重要な即時性と, デー夕久測に対する頑健さに 優れていることを示している．また，一回の予測解析が 完了し次第, 予測結果が自動描画されウェブブラウザで 確認できるため, ユーザーは即座に予測結果を確認する ことができる，この点も，迅速さが重要な津波予測の場 面での利点になると期待される.

上記のように, 本研究で沖合津波観測デー夕同化シス テムを開発したことにより，実用化に向けた津波即時予 測実験を行うための基盤を強化することができた．今後 は, 過去の津波実記録への適用や想定巨大地震を対象と した数值実験を進めることで, 本システムの性能をより 詳細に評価するとともに, 実運用化に向けて強化すべき 機能の検討を進める必要がある。そうして得られた知見 や検討結果は, 将来, 本格的な実運用システムを構築す る際の重要な参考情報になるものと期待される.

謝辞 : 本システムは, 東日本大震災復興関連事業のため の平成 23 年度第三次補正予算を用いて開発した。また, 本研究の一部は,「HPCI 戦略プログラム」(分野3) 防 災・減災に資する地球変動予測の補助を受けて実施し た. 本研究で使用したケーブル式海底水圧計の記録は, 気象庁, 東京大学地震研究所, 海洋研究開発機構から提 供を受けたＧPS 波浪計の記録は，国土交通省港湾局か ら提供を受けた。検潮所の潮位記録は, 気象庁から提供 を受けた。陸上GPSの即時解析結果は, 東北大学の太田 雄策博士から提供を受けた。本論文の図の一部は, Generic Mapping Tools（Wessel・Smith, 1998）を用いて
作図された。ここに記して，感謝の意を表する．

\section{参 考 文 献}

気象庁（2011）：平成23年（2011年）東北地方太平洋沖地震, 平成 23 年 3 月地震 ・ 火山月報 (防災編), pp. 57-148.

斎藤正德（1978）：漸化式ディジタル・フィルターの自動設計, 物理探鉱，第31巻，112-135.

唇巳大介・富田孝史（2008）：震央位置を考慮したインバー ジョン手法によるリアルタイム津波予測, 海岸工学論文 集, 第 55 巻, pp. 246-250.

林 豊（2010）：GPS波浪計の長周期波形観測值による沿岸津 波換算值を活用した津波即時情報，自然災害科学，第 29 巻, 3 号, 381-391.

藤沢 格・立山清二・舟崎 淳 (1986) : 房総沖海底地震常時 観測システムの概要，測候時報，第53巻，127-166.

安田誠宏・高山知司・川村健太・間瀬 肇（2007）：沖合観 測情報を用いたインバージョン法によるリアルタイム津 波予測, 海岸工学論文集, 第54卷, pp. 196-200.

Hirata, K., M. Aoyagi, H. Mikada, K. Kawaguchi, Y. Kaiho, R. Iwase, S. Morita, I. Fujisawa, H. Sugioka, K. Mitsuzawa, K. Suyehiro, H. Kinoshita and N. Fujiwara (2002): Real-time geophysical measurements on the deep sea-floor using submarine cable in the southern Kurile subduction zone, IEEE J. Oceanic Eng., Vol.27, No.2, 170-181.

Kanazawa, T. and A. Hasegawa (1997): Ocean-bottom observatory for earthquakes and tsunami off Sanriku, north-east Japan using submarine cable, International Workshop on Scientific Use of Submarine Cables, Comm. for Sci. Use of Submarine Cables, Okinawa, Japan, 208-209.

Kato, T., Y. Terada, K. Ito, R. Hattori, T. Abe, T. Miyake, S. Koshimura and T. Nagai (2005): Tsunami due to the 2004 September 5 th off the Kii peninsula earthquake, Japan, recorded by a new GPS buoy, Earth Planets Space, Vol.57, 297-301.

Matsumoto, K., T. Takanezawa and M. Ooe (2000): Ocean tide models developed by assimilating TOPEX/POSEIDON altimeter data into hydrodynamical model: A global model and a regional model around Japan, J. Oceanogr., Vol.56, 567-581, doi:10.1023/A:1011157212596.

Ohta, Y., T. Kobayashi, H. Tsushima, S. Miura, R. Hino, T. Takasu, H. Fujimoto, T. Iinuma, K. Tachibana, T. Demachi, T. Sato, M. Ohzono and N. Umino, (2012): Quasi real-time fault model estimation for near-field tsunami forecasting based on RTKGPS analysis: Application to the 2011 Tohoku-Oki earthquake (Mw 9.0), J. Geophys. Res., Vol.117, B02311, doi:10.1029/2011JB008750.

Tsushima, H., R. Hino, H. Fujimoto, Y. Tanioka and F. Imamura (2009): Near-field tsunami forecasting from cabled ocean bottom pressure data, J. Geophys. Res., Vol.114, B06309, doi:10.1029/2008JB005988.

Tsushima, H., K. Hirata, Y. Hayashi, Y. Tanioka, K. Kimura, S. Sakai, M. Shinohara, T. Kanazawa, R. Hino and K. Maeda (2011): Near-field tsunami forecasting using offshore tsunami data from the 2011 off the Pacific coast of Tohoku Earthquake, Earth Planets Space, Vol.63, pp. 821-826, doi:10.5047/ eps.2011.06.052.

Tsushima, H., R. Hino, Y. Tanioka, F. Imamura and H. Fujimoto (2012): Tsunami waveform inversion incorporating permanent seafloor deformation and its application to tsunami forecasting, J. Geophys. Res., Vol.117, B03311, doi:10.1029/ 2011JB008877.

Wessel, P. and W. H. F. Smith (1998): New, improved version of Generic Mapping Tools released, Eos Trans. AGU, Vol.79, pp. 579 . 